TITLE:

\title{
Evaluation of a Compressive-Type Skeletal Muscle Pump for Cardiac Assistance(Abstract_要旨)
}

$\operatorname{AUTHOR}(S)$ :

Mizuhara, Hisao

\section{CITATION:}

Mizuhara, Hisao. Evaluation of a Compressive-Type Skeletal Muscle Pump for Cardiac Assistance. 京都大学, 2000, 博士 (医学)

ISSUE DATE:

2000-03-23

URL:

http://hdl.handle.net/2433/180894

RIGHT: 
氏 名 水原装势

学位(専攻分野) 博 士 (医 学)

学位記番号論医博第 1710 号

学位授与の日付平成 12 年 3 月 23 日

学位授与の要件 学 位 規 則 第 4 条第 2 項該 当

学位論文題目 Evaluation of a Compressive-Type Skeletal Muscle Pump for Cardiac Assistance

（心補助を目的とした圧縮型骨格筋ポンプの評価）

論文調查委員教授清水慶彦教授篠山重威教授米田正始

\section{論 文 内容 の 要 旨}

重症心不全患者の唯一の救命手段である心移植に代わる手段がいくつか模索されている。植え込み型人工心荿がその代表 であるが，自己の骨格筋（広背筋）の収縮力を応用する，いわゆる骨格筋ポンプは第三の手段として注目されている。その 応用方法として直接心臓に巻きつける方法, ロール状に巻き心室を形成する方法の二つの研究が主に報告されている。しか しながらいずれる動脈の切断を伴う大きな剥離が必要で，それに由来する遠隔期の線維化，また収縮力の強い中枢側を十分 に利用できないなどの欠点を有している。そのため本研究では, in-situのままの広背筋を循環補助に利用する新しい方法を 考案し，その可能性について検討した。

〈方法〉実験対象は平均体重 $13.2 \mathrm{Kg}$ の雑種成犬 22 匹とし，全身麻醉下に施行した。まず筋肉の直線的収縮力を空気圧に 変換する actuator として,ドーム状バルーンを作成し, 左側胸部の広背筋と胸壁との間に挿入した。電気刺激により収縮し た広背笳がバルーンを圧縮 (圧縮型骨格筋ポンプ) させ, バルーン内に発生した空気圧で空気駆動型補助人工心葴 (Circulatory assist device, CAD）を駆動させることを目的とした。

（1）基礎実験：効果的な空気圧発生の条件を検討する目的で, バルーンの形態, 挿入部位による圧発生の影響, バルーン が筋肉組織血流に与える影響を検討した。

（2）慢性実験：基礎実験の結果に基づき, 慢性期のバルーンの機能と広背筋の動力源としての能力を検討した。すなわち 初回手術にてバルーンとペースメーカーを植え込み, 広背筋に 12 週間の連続的電気刺激を与え (Muscle Conditioning), 耐疲労性を獲得させた後に再手術を施行した。植え込まれたバルーンを模擬循環回路内の CAD に連結後, バルーン内発生 圧にて駆動させ, そのポンプ能の評価を行う。

〈結果〉

（1）基礎実験：圧発生能は，最も収縮性に富む近位部（第三肋間）扦入において有意に（p<0.05）高く，最大 $140 \mathrm{mmHg}$ の圧增加が得られた。またバルーンサイズはその発生圧に影響を与え, 本実験系では $38 \mathrm{ml}$ のバルーンが最む高い発生圧が 得られた。筋肉下に挿入したバルーンは静止時内圧 $40 \mathrm{mmHg}$ の拡張で, 筋肉組織血流が $23.3 \%$ 低下した $(\mathrm{p}<0.05)$ 。

（2）慢性実験：Muscle Conditioning の施行により，圧発生能は未施行例の平均 $80 \%$ に低下した。またバルーン周囲の 癒着はその発生圧を非癒着例に比し最大 $34 \%$ 低下させた（ $\mathrm{p}<0.005 ） 。 \mathrm{CAD}$ の一回拍出量 (SV) は心室バイパス（VB）の 条件下では後負荷 $50 \mathrm{mmHg}$ 以下で, また大動脈カウンターパルセーション（ACP）の条件下では後負荷 $80 \mathrm{mmHg}$ 以下で, それぞれ正常 SV の $15 \mathrm{ml}$ を上回った。CAD の一回拍出仕事量は $0.87 \times 10^{6} \mathrm{erg}$ と成犬右室仕事量 $\left(0.2 \times 10^{6} \mathrm{erg}\right)$ を上 回ったが, 左室仕事量 $\left(2.0 \times 10^{6} \mathrm{erg}\right)$ を下回った。VBにおいて心拍数 $70 /$ 分以上でそれ以下に比較し SV が $36 \%$ 低下し たが，ACPにおいてはSVの変化は見られなかった。

〈まとめ〉広背筋を利用した圧縮型骨格筋ポンプは, 左心室の置換としては困難であるあのの, 右心バイパスおよび大動脈 カゥンターパルセーションの駆動は十分に可能であった。癒着に伴う効率低下, 心拍追従性など問題点が存在するすのの, 
循環補助の動力源として応用可能であることが示された。本研究は in-situ の広背筋を循環補助に応用する最初の報告とし て，骨格筋ポンプ分野の発展に寄与すると思わる。

\section{論文蕃查の結果の要旨}

重症心不全に対する外料治療の一つに，自己の骨格筋を応用する骨格筋ポンプがある。骨格筋の応用方法として従来行わ れてきた Dynamic Cardiomyoplasty 以外に, 補助循環装置の駆動力として応用可能かどうか検討した。その手段として in-situ 広背筋下に挿入する chamber を試作し, 筋肉の圧縮力を空気圧に転換させる Muscle actuator として使用（圧縮型 骨格筋ポンプ), 生じた空気圧にて空気駆動型の補助循環装置（以下 CAD）を駆動させることを目的とした。

研究 I として, in-situ広背筋から効率良く power 引引出すための基礎的検討を雑種成犬を実験対象として行った。そ の結果広背筋の中枢側を応用し，至適な chamber volume の chamber を使用することで最大の発生圧が得られた。また 40 $\mathrm{mmHg}$ 以上の chamber 圧が持続すると広背筋の組織血流が有意に障害させることが判明した。

研究 Iの結果を応用し, 研究 II では広背筋下に植え込んだ chamber の慢性期での機能および, 電気的 Conditioning を施 行した後の広背筋を使用し, 発生エネルギーを評価した。長期移植した chamber の周囲には縄維性皮膜が形成され, chamber の圧発生能を最大 $35 \%$ 減じた。Chamber の発生圧にて駆動させた, CAD の一回拍出仕事量は $0.87 \times 10^{6} \mathrm{erg}$ で実験対 象大の正常右室一回拍出仕事を上まわるものの, 正常左室一回拍出仕事には至らなかった。しかしながら大動脈カウンター パルセーターとして用いることで，体循環の後負荷に対しても十分な効果が得られた。以上の研究は in-situ広背筋を用い， その補助循環の軀動源としての能力を初めて明らかにしたものである。

したがって, 本論文は博士 (医学) の学位論文として価值あるものと認める。

なお，本学位授与申請者は，平成 12 年 3 月 3 日実施の論文内容とこれに関連した諮問を受け，合格と認められたものであ る。 